$$
J A \# 1286
$$

$10^{4}$ 


\title{
Soil management options to reduce runoff and erosion on a hardsetting Alfisol in the semi-arid tropics
}

\author{
G.D. Smitha, K.J. Coughlan ${ }^{a}$, D.F. Yule ${ }^{a}$, K.B. Laryea ${ }^{b}$, K.L. Srivastavab , N.P. \\ Thomas $^{c}$ and A.L. Cogle \\ -Land Management Research Branch, Queensland Department of Primary Industries, GPO Box 46. \\ Brisbane, Qld., Australia \\ ${ }^{b}$ Resource Management Program, International Crops Research Institute for the Semi-Arid Tropics, \\ (ICRISAT), Patancheru, 502324 Andhra Pradesh, India \\ 'The Nizam's Medical Institute, Panjaguta, Hyderabad, Andhra Pradesh, India
}

(Accepted 6 February 1992)

\section{ABSTRACT}

Smith, G.D., Coughlan, K.J., Yule, D.F., Laryea, K.B., Srivastava, K.L., Thomas, N.P. and Cogle, A.L., 1992. Soil management options to reduce runoff and erosion on a hardsetting Alfisol in the semi-arid tropics. Soil Tillage Res., 25: 195-215.

Improved farming systems are needed to enhance productivity and reduce degradation on hardsetting Alfisols in the semi-arid tropics. A long-term experiment was started in July 1988 at ICRISAT, Hyderabad, India, to evaluate practices to improve infiltration and reduce erosion by stimulating biological activity and protecting soil in the rainy season. This paper outlines the rationale for the experiment, describes it, and summarises early results. Fifteen treatments in a randomised block design were applied to plots $28.5 \mathrm{~m}$ long by $5 \mathrm{~m}$ wide on a $2 \%$ slope. Nine annual treatments made up a factorial sub-set: tillage by tined implement to three depths $(0,10$ and $20 \mathrm{~cm})$ combined with three mulch treatments (no mulch, farmyard manure (FYM) at $15 \mathrm{tha}^{-1}$, and rice straw at $5 \mathrm{t} \mathrm{ha}^{-1}$ ). Pearl millet (Pennisetum glaucum) was sown in the factorial sub-set in July 1988. Six perennial species ley treatments (combinations of perennial pigeonpea (Cajanus cajan), verano stylo (Stylosanthes hamata), and buffel grass (Cenchrus ciliaris)) completed the randomised block design. All treatments were replicated three times making 45 plots in total. Plots were instrumented to measure runoff and soil loss.

Millet straw yield was reduced by tillage to $20 \mathrm{~cm}$ and grain yield was significantly reduced by tillage to both 10 and $20 \mathrm{~cm}$. Mulches had no effect on millet straw yield but FYM significantly increased millet grain yield. The proportion of rainfall running off plots ranged from 15.8 to $39.1 \%$. Perennia: species treatments tended to have higher runoff than treatments under millet, but this was not consistent as zero tillage without mulch, and tillage to $10 \mathrm{~cm}$ either with mulch or with FYM mulch, alsc had relatively high runoff. Rice straw mulch significantly reduced runoff by comparison with FYN and no mulch. Soil was lost mainly as suspended load, indicating that raindrop detachment was the main erosion process. Effects of perennial species were variable and probably reflected the degree 0 :

Correspondence to: G.D. Smith, Land Management Research Branch, Queensland Departmen of Primary Industries, GPO Box 46, Brisbane, Qld., Australia. 
surface protection provided in this establishment phase. Tillage significantly increased suspended load concentration in the first major runoff event but not in an event later in the season. Rice straw mulch significantly reduced bed load concentration in the first event and reduced suspended load in the later event. The ability of straw mulch to reduce runoff volume and sediment concentration suggests mulch-based systems may be able to contribute to sustainability of farming systems in the semiarid tropics. The lack of beneficial effects from tillage suggests a limited role for tillage-based systems. Results from subsequent years are needed to form definite conclusions and to show effects of slower biologically-induced changes in the soil.

\section{INTRODUCTION}

\section{Background}

Alfisols cover about one-third of the land in the semi-arid tropics (SAT) (Kampen and Burford, 1980). Despite their importance in food production for the growing populations of this region, productivity of these soils has remained low and unstable owing to climate- and soil-related contraints (Swindale, 1982). The climate-related constraints include short rainy seasons, variability in the timing and amount of rainfall, high intensity rains resulting in high runoff, high temperatures, and high rates of evaporation (Kampen, 1980; Virmani et al., 1980; Sivakumar et al., 1987). Many Alfisols have soil physical characteristics that increase the impact of poor seasonal conditions. For example, the low strength of saturated soil leads to surface sealing under raindrop impact, slumping of surface roughness, and high soil erodibility by water; high sand or gravel content reduces plant available water capacity; an argillic horizon in the shallow subsoil acts as a throttle to water movement; weathered parent material (murrum) restricts root proliferation; and soil strength often increases markedly as the soil dries (hardsetting; Mullins et al., 1987, 1990 ) which restricts tillage effects, seedling emergence and root system development (Arndt, 1965; El-Swaify et al., 1984, 1985, 1987). The high strength of dry soil makes preparation of a seedbed very difficult until rain softens the soil. The combination of climate and soil factors means there is usually a very narrow 'window of opportunity' when crops can be successfully! established. Furthermore, farmers in the SAT usually have very limited resources at their disposal.

Although there has been research on land management practices to resolve these problems there is as yet no technology for optimising the productivity of Alfisols under rainfed conditions. El-Swaify et al. (1984) concluded that an improved land use system will be technically feasible if it satisfies some of the following interrelated objectives: (1) improved water use efficiency and access to available resources; (2) maintained or enhanced soil fertility; (3) improved soil aggregation and reduced surface sealing and crusting; (4) decreased runoff and soil erosion; (5) increased structural stability of the soil; 
(6) reduced pest and disease incidence. They also conclude that component research is essential for an understanding of the general principles, and for indicating how location-specific land use systems may be tailored to suit contrasting Alfisol regions. El-Swaify et al. (1984) advocated priority for research on runoff and soil loss, the role of tillage, soil structure, methods of enhancing and maintaining soil organic matter, and alternative land use systems including agroforestry and grass/legume ley farming.

Soil management in rainfed cropping systems for Alfisols should aim to ensure that soil physical properties at the start of the wet season favour effective water entry and storage, easy seedbed preparation, and low-risk crop establishment. In essence, infiltration is the key process. If infiltration rate is adequate, water storage is maximised and runoff, with concomitant soil erosion, is minimised. While soil erosion threatens sustainability of Alfisol production systems (Sanchez, 1976), this threat is posed by the cumulative effect of many runoff events. Management practices that change soil structure to maximise infiltration will, by increasing wet soil strength, also reduce the erodibility of the soil when runoff does occur. Such practices are likely to be acceptable to farmers because they help them meet their short-term production goals and promote the long-term stability of the system.

\section{Options for improved land management}

\section{Tillage}

Primary and secondary tillage requirements depend on the properties of the particular soil and seasonal conditions. In the main, the benefits of tillage are due to better seedbeds, better root growth, improved water storage and weed control (El-Swaify et al., 1984, 1985, 1987). Deep tillage can reduce soil bulk density and strength in the argillic subsoil and promote root system development, but the yield response depends on soil features, seasonal conditions, crop type, time of sowing and soil fertility (Charreau and Fauck, 1970; Charreau and Nicou, 1971; Charreay, 1972; Nicou and Chopart, 1979; Vittal et al., 1983; Vijayalakshmi, 1987; Chopart, 1989). Dry-season tillage has been shown to increase yield, probably because it presents an open, porous surface that traps and absorbs the early rains (Hadimani and Perur, 1971; Hadimani et al., 1982; Hoogmoed, 1987; Sinclair, 1987). It may also control weeds (Hegde et al., 1987; Sinclair, 1987) and mineralize nitrogen. Cogle et al. (1991) compared zero tillage and reduced tillage on an Alfisol in northern Australia, and found that weed control by tillage was more reliable than by herbicides.

Despite its benefits, tillage is often physically difficult for SAT farmers and it takes time and energy. Also, the beneficial effects on soil structure may be shortlived. Awadhwal and Smith (1990) found that bulk density and strength of the tilled layer of an Alfisol at Patancheru reverted to pre-tillage values 
within three or four wetting and drying cycles. Sinclair (1987) found that tillage improved early growth but did not increase grain yield in the season studied because the crop exhausted the additional soil water before grain-filling. He also found that tillage, if followed by wetting, increased crust strength. This may have resulted from closer particle packing and enhanced interparticle bonding if clay content in the soil surface was increased due to soil inversion. It may also have been due to soil shearing during tillage increasing susceptibility of clay particles to dispersion (Emerson, 1983). As clay content increases in sandy soils, size and density of aggregates also increase (Smith et al., 1978). Farmers in the SAT sometimes spread sand on the surface to improve soil physical properties (Sachan and Smith, 1989). On the other hand, Pathak et al. (1987) used shallow, non-inverting tillage to increase illuviation of fine particles and thus raise the coarse sand content of the surface layer, thereby improving physical characteristics. Also, Hamblin (1984), Burch et al. (1986), and Chan and Mead (1988) concluded from direct drilling studies on structurally unstable, light textured, soils in southern Australia, that soil structural stability and infiltration were generally improved if soil was not disturbed.

Although tillage increases the porosity of the tilled layer, soil shearing may destroy continuity of macropores extending below the tilled layer (Ehlers, 1975). Whereas Vertisols have structure rebuilding capabilities due to the activity of clay minerals (Coughlan, 1984; Smith, 1984), Alfisols are essentially rigid and damage to soil structure may be permanent. Macrofauna may play a vital role in creating continuous macropores in such soils (Blackwell and Blackwell, 1989). However, tillage discourages soil macrofauna (Abbott et al., 1979). Organic carbon levels are relatively low in Alfisols of the SAT (Jones, 1973; El-Swaify et al., 1987). This suggests that fertility and structural stability will also be low in these soils. Dalal and Mayer (1986) found that soil organic matter declined in tilled Vertisols in the subtropics of Queensland. Therefore, there is little prospect that organic matter levels can be increased in Alfisols under tillage-based systems. Thus, tillage is a shortterm remedy for physical problems, but it may aggravate these problems ip the long term. In essence it creates a cycle of decline in which tillage increase. the need for tillage to maintain infiltration capacity.

\section{Surface configurations}

Surface configurations, such as tied ridges, can be used to trap water on the soil surface when rainfall rate exceeds infiltration rate (Lawes, 1961, 1963, 1966; Pereira et al., 1967; Dagg and Macartney, 1968). Because surface roughness soon disappears on structurally unstable soils, it is usually necessary to reform the configurations at the start of each rainy season, an operation that normally is most effective after the soil has been loosened by both primary and secondary tillage operations. Surface configurations are there- 
fore unlikely to be useful to promote effectiveness of early wet season rains. Their main use will be to improve water storage during the crop-growing season. However, if infiltration rate is so low (or rain so frequent) that water ponding on the surface induces waterlogging, surface configurations can have a detrimental effect on crop growth (Lawes, 1963; Dagg and Macartney, 1968; Kowal, 1970; Perrier, 1987).

\section{Biological agents}

Plants or plant remains influence soil biological activity by providing protection and a food source. Several authors have reported benefits from surface mulching (Lal, 1975; Gupta and Gupta, 1986; El-Swaify et al., 1987; Perrier, 1987). It is often assumed that mulches or surface litter take the place of crop or natural vegetation canopy in protecting the soil from raindrop impact (Lal et al., 1980; Bridge et al., 1983a). In hardsetting soils, permeability may be intrinsically low. Hence, protecting the soil against raindrop impact might have little effect. Bridge et al. (1983b) considered that surface litter and its effect on soil macrofauna was a key factor in regeneration of soil structure under pastures in Alfisols in northern Australia. Not only does the litter protect the surface against raindrop impact and reduce the rate of runoff, but it also modifies soil temperature and drying (Bristow, 1988; Bristow and Abrecht, 1989), and provides a food source for soil fauna.

Incorporation of organic amendments such as farmyard manure (FYM) and green manure crops has also been shown to improve yield and soil physical properties (Biswas et al., 1964; Charreau and Fauck, 1970; Bairathi et al., 1974; Venkateswarlu, 1987). This raises the question of whether it is better to leave organic materials on the surface or to incorporate them in the soil. Incorporation mixes the material within the soil and protects it from foraging animals. By stimulating microbial activity it should maximise the formation of structure-stabilising organic bonds. However, the amounts of organic materials available for return to the soil in the SAT are usually small, and the evidence suggests that trends in soil organic carbon in tillage-based systems are downwards (Dalal and Mayer, 1986). Because tillage also discourages soil macrofauna, incorporation is unlikely to maximise the overall benefits that might be available from biological agencies. For maximum benefits from a limited amount of organic material, it should be placed where it influences water entry processes in the immediate surface. It should protect the surface from raindrop impact, slow runoff, enrich the organic content and structural stability of the immediate surface, and encourage soil fauna. Because continuous macropores are important for water entry, the aim should be to provide a suitable habitat so that macrofauna will create a macropore network extending through the zone of poor physical properties. If this network is not disturbed by tillage, and humic materials are preferentially distributed around 
because they cause soil disturbance similar to that of the wooden country plough used by Indian farmers. Tines were mounted on a tractor-drawn toolbar and $T_{10}$ and $T_{20}$ plots were subjected to one pass with the depth set at 10 $\mathrm{cm}$. Chisel tines, $4 \mathrm{~cm}$ wide and spaced $60 \mathrm{~cm}$ apart, were passed once through $T_{20}$ plots after the shallow tillage operation. These chisel tines had been used earlier at ICRISAT in tillage studies with bullock-drawn equipment. Hence, although a tractor was used, the soil disturbance during deep tillage was consistent with that resulting from using animal traction power. Tillage operations were carried out in mid-July after the soil had been softened by rain. The tillage was carried out as late as possible before sowing and there was no secondary tillage apart from the disturbance associated with sowing.

\section{Mulch treatments}

Mulch treatments were either no mulch $\left(\mathrm{N}_{\mathrm{m}}\right)$, rice (Oryza sativa) straw (cut at ground level and carried from a nearby field) at $5 \mathrm{tha} \mathrm{h}^{-1}\left(\mathrm{R}_{\mathrm{m}}\right)$, or FYM (from ICRISAT bullock shed, applied air dry) at $15 \mathrm{t} \mathrm{ha}^{-1}\left(\mathrm{~F}_{\mathrm{m}}\right)$. Rice straw was used because it provides a high surface area per unit weight and, by comparison with sorghum straw, it is not as much in demand for other uses. Lal et al. (1980) found that rice straw increased soil fauna activities in an Alfisol in Nigeria when applied as a mulch at 6 and $10 \mathrm{t} \mathrm{ha}^{-1}$. Farmyard manure was applied at the relatively high rate of $15 \mathrm{tha}^{-1}$ because $5 \mathrm{t} \mathrm{ha}^{-1}$ applied over 8 years had no visible effect on soil structure on a similar soil (K.L. Sahrawat, personal communication, 1987). No mulch materials were applied to the perennial species ley treatments. The mulch treatments were applied within 10 days after sowing, as surface cover between the rows of emerging seedlings in the tillage treatments. The materials were not mechanically incorporated into the soil. This was to ensure that the soil surface was protected from temperature extremes, from raindrop impact and to provide a suitable habitat for soil fauna. Because the immediate soil surface controls many physical processes, concentrating the materials on the surface should maximise their effect in the critical early stages of the rainy season.

\section{Perennial species ley treatments}

Species selected for use, alone or in combinations as shown in Table 4, were buffel grass (Cenchrus ciliaris), verano stylo (Stylosanthes hamata) and perennial pigeonpea. Perennial pigeonpea was selected because of the beneficial effect of pigeonpea on the subsequent crop (Kumar Rao et al., 1983), the promise shown by the perennial cultivars for use in agroforestry systems, and its ability to develop roots into the murrum (R.P. Singh and C.K. Ong, personal communication, 1987). Buffel grass and verano were selected on the basis of their earlier good performance in observation trials at ICRISAT 
(M.M. Sharma, personal communication, 1987) and on Alfisols in India (R.P. Singh, and Y.P. Singh, personal communication, 1987). The effects of these species on soil structure were not known, but it was considered preferable to use species that might be acceptable to farmers on the basis of productivity of high-quality fodder rather than those renowned for their effects on soil structure. Verano fixes appreciable amounts of nitrogen and was the basis of ley pasture systems used on Alfisols in northern Australia by McCown (1987) and Cogle et al. (1991). Bridge et al. (1983b) found that verano and buffel grass had some potential to improve soil structure in Alfisols in northern Australia. Apart from the formation of sowing furrows, soil in these treatments was not tilled.

\section{Sowing}

Pearl millet (cultivar 'BK 560') was sown in the tillage depth $\times$ mulch type factorial on 26 July 1988 . Seeds were sown by hand in rows $60 \mathrm{~cm}$ apart. Small sowing furrows were formed by drawing the chisel tines at a depth of 5 $\mathrm{cm}$ in all tillage treatments. In $\mathrm{T}_{20}$ plots, the millet rows were located over the path of the deep tillage tines. Buffel grass and verano were sown in rows 38 $\mathrm{cm}$ apart. In mixed swards the species were sown in alternate rows. Perennial pigeonpea (cultivar 'ICPL 88040') was sown in rows $1 \mathrm{~m}$ apart, and plants within rows were $1.2 \mathrm{~m}$ apart. The seeds were covered with soil by hand-raking. Grass weeds were controlled by spraying with paraquat 1 week before the treatments were applied. Post-emergence weed control was by hand-sickle. A uniform millet stand was ensured by hand-thinning and transplanting 4 weeks after sowing. Diammonium phosphate fertiliser (18\% N, 20\% P) was broadcast by hand at a rate of $120 \mathrm{~kg} \mathrm{ha}^{-1}$ on all plots before sowing. Urea $(46 \%$ $\mathrm{N}$ ) was broadcast on millet plots at the rate of $100 \mathrm{~kg} \mathrm{ha}^{-1}$ on 5 September.

\section{Measurements}

Rainfall rate was measured at 1 min intervals with a Monitor Sensors tipping bucket $(0.2 \mathrm{~mm}$ per tip) pluviometer connected to a Campbell CR 10 logger. Plot runoff was channelled through a sediment collection trough and the flow rate was measured by a tipping bucket fitted with a magnet-operated reed switch monitored by the CR 10 logger. During rainfall the logger checked the reed switch circuits to each tipping bucket once per $\mathrm{s}$. When the bucket was at rest the magnet was either against or away from the reed switch, i.e. the circuit was either open or closed. A change in state of a circuit was recorded as a bucket tip. One bucket tip was equivalent to approximately 0.05 $\mathrm{mm}$ of runoff from the plots. Each bucket was calibrated over a range of flow rates in the laboratory and again after installation in the field. Tipping bucket design and calibration was described by Smith and Thomas (1988). 
Runoff bedload was collected in a trough $25 \mathrm{~cm}$ deep and $22 \mathrm{~cm}$ wide. Runoff flowed into the trough in a $50 \mathrm{~cm}$ section at either end and had to flow approximately $2 \mathrm{~m}$ to the outlet to the tipping bucket. After runoff events, most of the surplus water was drained from the trough. All of the deposited bed load was then collected through a drain plug and dried. Suspended load was sampled during the runoff event by a flow-splitting slot which sampled approximately 0.001 of the flow to the tipping bucket. Suspended load was subsampled, settled, dried and weighed and the concentration used to calculate the weight of suspended sediment. Soil water content and bulk density were measured at $0-5,5-10,10-15$ and $15-20 \mathrm{~cm}$ depth in all plots in the week beginning 12 September. Soil samples for nutrient analysis were also taken. Millet yield was measured by cutting and threshing a strip $20 \mathrm{~m}$ by 2 $\mathrm{m}$. Cenchrus and Stylosanthes plants were trimmed early in the growing season and were then allowed to go to seed to thicken the stand. Pigeonpea yield was measured by picking pods and trimming plants $80 \mathrm{~cm}$ above the ground.

\section{RESULTS AND DISCUSSION}

\section{Soil properties}

There were no significant differences between treatments in $\mathrm{pH}$, electrical conductivity, nitrogen, phosphorus, calcium, magnesium or sodium. However, rice straw mulch significantly increased potassium levels compared with no mulch ( 32 vs. $47 \mathrm{mg} \mathrm{kg}^{-1}$ ), but only in the $0-15 \mathrm{~cm}$ layer. We have no explanation for this result; presumably it is associated with the breakdown of the rice straw. There was no significant difference between treatments in soil water content or bulk density at any depth. This lack of persistence of any tillage effect on bulk density agrees with the findings of Awadhwal and Smith (1990).

\section{Pigeonpea yield}

Yields of pigeonpea cuttings and grain yield are presented in Table 1. Pigeonpea as a sole crop had significantly higher yield than either pigeonpea with Stylosanthes or pigeonpea with Cenchrus and Stylosanthes. The lower yield of pigeonpea when in combination with pasture species is attributed to competition for water and nutrients. The pigeonpea canopy was always above the understorey, hence competition for light was not a factor.

\section{Millet yield}

Yields of millet straw and grain are presented in Tables 2 and 3. Analysis of variance on the tillage $\times$ mulch factorial as a sub-set shows that tillage re- 


\section{TABLE 1}

Yield of pigeonpea cuttings and grain

\begin{tabular}{lll}
\hline Treatment & Cuttings $(\mathrm{dry})\left(\mathrm{kg} \mathrm{ha}^{-1}\right)$ & Grain $\left(\mathrm{kg} \mathrm{ha}^{-1}\right)$ \\
\hline Pigeonpea & 1359 & 685 \\
Pigeonpea and Stylosanthes & 391 & 179 \\
Pigeonpea, Stylosanthes and Cenchrus & 474 & 252 \\
$\mathrm{LSD}_{0.05}$ & 482 & 291 \\
\hline
\end{tabular}

\section{TABLE 2}

Effects of tillage depth and mulch on yield $\left(\mathrm{kg} \mathrm{ha}^{-1}\right)$ of millet straw'

\begin{tabular}{lllll}
\hline Mulch $^{2}$ & \multicolumn{2}{l}{ Tillage depth } & & \\
\cline { 2 - 5 } & $\mathrm{T}_{0}$ & $\mathrm{~T}_{10}$ & $\mathrm{~T}_{20}$ & Mear \\
\hline $\mathrm{N}_{\mathrm{m}}$ & 5850 & 4917 & 4450 & 5072 \\
$\mathrm{~F}_{\mathrm{m}}$ & 6162 & 5265 & 5294 & 5574 \\
$\mathrm{R}_{\mathrm{m}}$ & 5797 & 4590 & 3937 & 4775 \\
Mean & 5936 & 4924 & 4560 & 5140 \\
\hline
\end{tabular}

'Tillage depth, $P=0.058$; mulch, NS; tillage depth $\times$ mulch, NS; $\mathrm{LSD}_{0.05}$ for main effects, 1147.

${ }^{2}$ Abbreviations: $T_{0}$, no tillage; $T_{10}$, tillage to $10 \mathrm{~cm} ; T_{20}$, tillage to $20 \mathrm{~cm} ; N_{m}$, no mulch; $R_{m}$, rice straw at $5 \mathrm{tha}^{-1} ; \mathrm{F}_{\mathrm{m}}$, farmyard manure at $15 \mathrm{tha}^{-1}$.

\section{TABLE 3}

The effect of tillage depth and mulch on yield $\left(\mathrm{kg} \mathrm{ha}^{-1}\right)$ of millet grain

\begin{tabular}{lllll}
\hline Mulch & \multicolumn{2}{l}{ Tillage depth } & & \\
\cline { 2 - 5 } & $\mathrm{T}_{0}$ & $\mathrm{~T}_{10}$ & $\mathrm{~T}_{20}$ & Mean \\
& 1202 & 1057 & 1031 & 1096 \\
$\mathrm{~N}_{\mathrm{m}}$ & 1310 & 1307 & 1115 & 1244 \\
$\mathrm{~F}_{\mathrm{m}}$ & 1203 & 1162 & 867 & 1078 \\
$\mathrm{R}_{\mathrm{m}}$ & 1238 & 1175 & 1004 & 1139 \\
Mean & & &
\end{tabular}

'Tillage depth, $P=0.003, \mathrm{LSD}_{0.05}, 115, \mathrm{LSD}_{0.01}, 164 ;$ Mulch, $P=0.017$; tillage depth $\times$ mulch, NS. ${ }^{2}$ Abbreviations as for Table 2.

duced millet straw yield $(P=0.058)$ and grain yield $(P=0.003)$. Interactions between tillage depth and mulch were not significant. Millet straw and grain yields were significantly reduced by tillage to $20 \mathrm{~cm}$ compared with $T_{0}$ and $\mathrm{T}_{10}$. This result is unexpected because previous work at the ICRISAT Centre had found that deeper tillage improved root penetration into the argillic ho- 
rizon. There is no obvious reason why deeper tillage should have reduced yield under the conditions of the 1988 season. A possible explanation is that deep tillage, because it was necessarily done after rain had softened the soil, may have caused smearing and compaction adjacent to the tine marks. However, runoff data (Table 4) show no evidence of a reduction in infiltration

- due to compaction. The lack of any effect on infiltration also suggests that leaching of nutrients beyond the root zone is unlikely to be a cause of the reduced yield. Deep tillage increased surface roughness, and a combination of increased surface ponding and slower internal drainage might have caused denitrification and hence reduced yield but, as stated above, analyses showed no differences in soil nitrogen. Perhaps the lack of a positive effect of tillage

\section{TABLE 4}

Effects of tillage depth and mulch under millet, and of perennial species combinations on total runoff ( $\mathrm{mm}$ and percent of rainfall $(395.6 \mathrm{~mm})$ )

\begin{tabular}{|c|c|c|}
\hline 'Treatment' & Mean runoff $(\mathrm{mm})$ & \% rainfall \\
\hline $\begin{array}{l}T_{0} R_{m} M^{2} \\
T_{10} R_{m} M \\
T_{20} R_{m} M \\
T_{20} F_{m} M \\
T_{20} N_{m} M \\
T_{0} F_{m} M \\
P \\
T_{10} F_{m} M \\
P+S \\
S \\
T_{10} N_{m} M \\
T_{0} N_{m} M \\
P+S+C \\
C \\
C+S\end{array}$ & $\begin{array}{c}62.5^{\mathrm{a}} \\
76.0^{\text {ab }} \\
79.6^{\text {abc }} \\
101.6^{\text {bed }} \\
111.9^{\text {dede }} \\
112.3^{\text {ded }} \\
120.3^{\text {de }} \\
121.2^{\text {def }} \\
122.1^{\text {def }} \\
125.5^{\text {def }} \\
131.7^{\text {def }} \\
132.9^{\text {def }} \\
134.0^{\text {def }} \\
143.3^{\text {ef }} \\
154.8^{\text {f }}\end{array}$ & $\begin{array}{l}15.8 \\
19.2 \\
20.1 \\
25.7 \\
28.3 \\
28.4 \\
30.4 \\
30.6 \\
30.9 \\
31.7 \\
33.3 \\
33.6 \\
33.9 \\
36.2 \\
39.1\end{array}$ \\
\hline $\mathrm{LSD}_{0.0 \mathrm{~s}}$ & 33.92 & \\
\hline $\begin{array}{l}\text { Main effects, } \\
\mathrm{T}_{0} \\
\mathrm{~T}_{10} \\
\mathrm{~T}_{20} \\
\mathrm{~N}_{\mathrm{m}} \\
\mathrm{F}_{\mathrm{m}} \\
\mathrm{R}_{\mathrm{m}}\end{array}$ & $\begin{array}{l}\text { analysed as a sub-set } \\
102.6 \\
109.6 \\
96.5 \\
124.2^{b} \\
111.7^{\circ} \\
72.7^{\circ}\end{array}$ & actions NS) \\
\hline $\mathrm{LSD}_{0.03}$ & 19.44 & \\
\hline
\end{tabular}

'Treatments with the same superscript letter are not significantly different ( $P \leq 0.05)$.

${ }^{2}$ Abbreviations: $T_{0,}$ no tillage; $T_{10}$ tillage to $10 \mathrm{~cm} ; T_{20}$, tillage to $20 \mathrm{~cm} ; N_{m}$, no mulch; $R_{m}$, rice straw at $5 \mathrm{t} \mathrm{ha}^{-1} ; \mathrm{F}_{\mathrm{m}}$, farmyard manure at $15 \mathrm{tha}^{-1} ; \mathrm{M}$, millet; $\mathrm{P}$, pigeonpea; $\mathrm{S}$, Stylosanthes hamata; $\mathrm{C}$, Cenchrus ciliaris. 
is because it was not carried out as several dry season operations but rather as one operation after the initial rains. Mulches had no effect on straw yield but FYM increased $(P=0.017)$ grain yield compared with $N_{m}$ and $R_{m}$. This is attributed to improved nutrient availability rather than to any effect on soil physical properties.

Runoff

Rainfall between sowing and harvest of the pearl millet totalled $395.6 \mathrm{~mm}$ and $\mathrm{EI}_{30}$ (calculated as per Rosenthal and White, 1980) totalled $163 \mathrm{t} \mathrm{m}^{-1}$ $\mathrm{ha}^{-1} \mathrm{~h}^{-1}$. Runoff occurred (at least in some plots) in nine rainfall events: Event A, 5 August 1988, rainfall $12 \mathrm{~mm}$; Event B, 12 August 1988, $21.4 \mathrm{~mm}$; Event C, 15 August 1988, $46 \mathrm{~mm}$; Event D, 18 August 1988, $41.4 \mathrm{~mm}$; Event E, 28 August 1988, $40.8 \mathrm{~mm}$; Event F, 31 August 1988, $30.8 \mathrm{~mm}$; Event G, 1 September 1988, $39.8 \mathrm{~mm}$; Event H, 2 September 1988, $11.8 \mathrm{~mm}$; and Event I, 20 September $1988,8.8 \mathrm{~mm}$. Mean total runoff (Table 4) ranged from 62.5 to $154.8 \mathrm{~mm}(15.8-39.1 \%$ of rainfall ). From the ranking in Table 4, treatments with millet tended to have lower runoff. Possible explanations are that water use by the millet caused a higher soil water deficit when rain fell and that the canopy protected the soil surface from raindrop impact. Two treatments under millet $\left(T_{0} N_{m} M\right.$ and $T_{10} N_{m} M$ ) had relatively high runoff possibly due to surface sealing before the canopy developed. Treatments with rice straw mulch had relatively low runoff, whereas those with Cenchrus had relatively high runoff. The relatively high runoff from treatments that include Cenchrus, is attributed to the tussock growth habit of this grass and to slow development of ground cover and surface litter between the tussocks.

Analysis of variance for the factorial sub-set (Table 4) shows that effects of tillage depth were not significant, but for mulch, rice straw significantly $(P<0.001)$ reduced runoff compared with FYM and no mulch. The lack of a significant tillage effect on runoff suggests that either the argillic horizon throttle was not altered by tillage operations, or that tillage has only a shortlived effect and a throttle re-forms at, or close to, the surface in this soil. The strong effect of rice straw in reducing runoff (compare $T_{0} R_{m} M$ and $T_{10} R_{m}$ $M$ with $T_{0} N_{m} M$ and $T_{10} N_{m} M$ in Table 4) is unlikely to be solely due to protection of the surface from raindrop impact. This is because the soil in all tillage treatments is at least partially protected from raindrop impact by the millet canopy. Rice straw could reduce runoff by: (i) reducing the rate of soil wetting and raindrop impact and hence reducing aggregate breakdown; (ii) slowing runoff and increasing the time available for infiltration; (iii) increasing the proportion of the plot surface that is ponded, thereby exposing more permeable areas for infiltration; (iv) increasing the infiltrability of the soil by increasing the activity of soil burrowing fauna. Farmyard manure did not 
reduce runoff. This suggests that the effect of straw was not solely because it provided a food source for soil organisms.

These results suggest that treatments similar to traditional tillage-based farming practices do not maximise infiltration and minimise runoff. Shallow tillage might improve sowing conditions and control weeds, but cover in contact with the soil surface seems essential for maximum in situ water conservation.

\section{Soil loss}

Bed load was measured as the weight of sediment in the trough; suspended load was the weight of sediment in the water sampled by the flow splitter. The suspended load dataset for some events was incomplete because samples were lost due to insects, spiders or debris blocking the flow-splitting device, or due to leakage or accident. Consequently, total soil loss for the season was estimated by summing across events the product of runoff volume and average sediment concentration within each treatment. These estimates range from 0.7 to $3.8 \mathrm{tha}^{-1}$; they give an indication of the order of total soil loss for the season but, being based on average concentrations, they were not statistically analysed. A full dataset was available for Events $\mathrm{C}$ and $\mathrm{F}$ and the analysis of variance is summarised (Table 5) to show treatment effects on soil loss processes twice in the season. Event $C$ was the first, and Event $F$ the fourth event that caused runoff from all plots. The concentration of suspended load (Table 5) decreased considerably (about six-fold) between Events $C$ and F, probably because of soil consolidation and an increase in the amount of protective plant cover. Bed load decreased about two-fold between Event $C$ and Event $F$. The concentration of suspended load was higher than that of bed load in these events (often by an order of magnitude), indicating that erosion was mainly by raindrop detachment and suggesting that nutrient enrichment in sediments could be high.

For Event C (Table 5), there was no consistent pattern in the effect of the perennial species or the tillage and mulch treatments. This was the first major runoff event of the season and sediment detachment and delivery processes might not have stabilised. Also, treatments with relatively low runoff could have had relatively high sediment concentrations because the material available for erosion was not diluted by large flow volumes. The analysis of variance within the factorial sub-set (Table 5) shows that tillage significantly increased suspended load concentration, but had no effect on bed load. The effect on suspended load suggests that tillage reduced soil strength and made soil more easily entrained; the lack of effect on bed load suggests that surface roughness aided deposition.

For Event $F$ (Table 5), the only consistent trend was for rice straw mulch treatments to have the lowest bed and suspended load concentrations. Within 


\section{TABLE 5}

Effects of tillage depth and mulch under millet, and of perennial species combinations on concentration of bed and suspended load in Events $C$ and $F$

\begin{tabular}{|c|c|c|c|c|}
\hline Treatment ${ }^{1}$ & $\begin{array}{l}\text { Bed load } \\
\text { (Event C) } \\
\mathrm{kg} \mathrm{m}^{-3}\end{array}$ & $\begin{array}{l}\text { Suspended } \\
\text { load } \\
\text { (Event C) } \\
\mathrm{kg} \mathrm{m}^{-3}\end{array}$ & $\begin{array}{l}\text { Bed load } \\
\text { (Event F) } \\
\mathrm{kg} \mathrm{m}^{-3}\end{array}$ & $\begin{array}{l}\text { Suspended } \\
\text { load } \\
\text { (Event F) } \\
\mathrm{kg} \mathrm{m}^{-3}\end{array}$ \\
\hline$T_{0} N_{m} M^{2}$ & $0.21^{\mathrm{abcd}}$ & $2.97^{\mathrm{ab}}$ & $0.12^{\mathrm{ab}}$ & $1.01^{a b c}$ \\
\hline $\mathrm{T}_{0} \mathrm{~F}_{\mathrm{m}} \mathrm{M}$ & $0.27^{\mathrm{abcd}}$ & $2.77^{\mathrm{ab}}$ & $0.32^{b}$ & $0.88^{\mathrm{abc}}$ \\
\hline $\mathrm{T}_{0} \mathrm{R}_{\mathrm{m}} \mathrm{M}$ & $0.11^{\mathrm{ab}}$ & $5.01^{a b c}$ & $0.03^{a}$ & $0.20^{\circ}$ \\
\hline $\mathrm{T}_{10} \mathrm{~N}_{\mathrm{m}} \mathrm{M}$ & $0.43^{d}$ & $8.14^{b c}$ & $0.15^{\mathrm{ab}}$ & $0.97^{a b c}$ \\
\hline $\mathrm{T}_{10} \mathrm{~F}_{\mathrm{m}} \mathrm{M}$ & $0.34^{\mathrm{abcd}}$ & $5.23^{\mathrm{abc}}$ & $0.13^{a b}$ & $0.97^{a b c}$ \\
\hline$T_{10} R_{m} M$ & $0.18^{\mathrm{abc}}$ & $5.92^{\mathrm{abc}}$ & $<0.01^{\circ}$ & $0.33^{a}$ \\
\hline $\mathrm{T}_{20} \mathrm{~N}_{\mathrm{m}} \mathrm{M}$ & $0.34^{\mathrm{abcd}}$ & $10.61^{c}$ & $0.15^{a b}$ & $1.25^{\mathrm{bcd}}$ \\
\hline $\mathrm{T}_{20} \mathrm{~F}_{\mathrm{m}} \mathrm{M}$ & $0.21^{\mathrm{abcd}}$ & $6.96^{\mathrm{abc}}$ & $0.20^{\mathrm{ab}}$ & $1.73^{\mathrm{cd}}$ \\
\hline$T_{20} R_{m} M$ & $0.13^{a b c}$ & $5.35^{\mathrm{abc}}$ & $0.04^{\star}$ & $0.17^{a}$ \\
\hline $\mathbf{P}$ & $0.35^{\text {bcd }}$ & $2.88^{\mathrm{ab}}$ & $0.06^{\prime \prime}$ & $0.85^{\text {ab }}$ \\
\hline$P+S$ & $0.10^{\circ}$ & $2.20^{\circ}$ & $0.16^{\text {ab }}$ & $0.41^{a b}$ \\
\hline $\mathrm{P}+\mathrm{S}+\mathrm{C}$ & $0.36^{\text {cd }}$ & $1.62^{\mathrm{a}}$ & $0.10^{\mathrm{ab}}$ & $0.34^{a}$ \\
\hline C & $0.10^{a}$ & $5.57^{\mathrm{abc}}$ & $0.18^{a b}$ & $2.00^{d}$ \\
\hline$C+S$ & $0.12^{a b c}$ & $6.51^{a b c}$ & $0.11^{\mathrm{ab}}$ & $0.36^{\mathrm{ab}}$ \\
\hline $\mathbf{S}$ & $0.18^{\mathrm{abc}}$ & $3.66^{\mathrm{ab}}$ & $0.11^{a b}$ & $0.30^{2}$ \\
\hline $\mathrm{LSD}_{0.05}$ & 0.247 & 5.755 & 0.255 & 0.857 \\
\hline
\end{tabular}

Main effects, factorially analysed as a sub-set (all interactions NS)

$\begin{array}{lllll}\mathrm{T}_{0} & 0.20 & 3.73^{\mathrm{a}} & 0.16 & 0.71 \\ \mathrm{~T}_{10} & 0.32 & 6.40^{\mathrm{b}} & 0.10 & 0.76 \\ \mathrm{~T}_{20} & 0.22 & 7.60^{\mathrm{b}} & 0.13 & 1.05 \\ \mathrm{~N}_{\mathrm{m}} & 0.33^{\mathrm{b}} & 7.20 & 0.15^{\mathrm{ab}} & 1.10^{\mathrm{b}} \\ \mathrm{F}_{\mathrm{m}} & 0.27^{\mathrm{b}} & 4.95 & 0.22^{\mathrm{b}} & 1.19^{\mathrm{b}} \\ \mathrm{R}_{\mathrm{m}} & 0.14^{\mathrm{a}} & 5.57 & 0.03^{\mathrm{a}} & 0.23^{\mathrm{a}} \\ \mathrm{LSD}_{\text {n.os }} & 0.125 & & & \\ \end{array}$

'Treatments with the same superscript letter are not significantly different $(P \leq 0.05)$.

${ }^{2}$ Abbreviation: see Table 4.

the factorial sub-set (Table 5), rice straw mulch significantly reduced bed load compared with FYM but not compared with no mulch. This suggests that some FYM was washed off the plots but, considering the rate of application, relatively little was lost. Suspended load concentration was significantly reduced by rice straw mulch by comparison with $N_{m}$ and $F_{m}$ which suggests that raindrop impact was the main detachment mechanism and that the FYM did not protect the soil. The lack of significant tillage effects on suspended load concentration (in contrast to Event $C$ ) suggests that the tilled soil had consolidated.

The results for these events show that soil loss was mainly in the form of 
suspended load. The small proportion of bed load may have been because active rills had not formed and soil was eroded mainly by rainfall detachment. Treatments appeared to reduce erosion by protecting the soil surface rather than by increasing soil strength. Neither the millet canopy nor the cover provided by the perennial species fully protected the soil from erosion. The treatment approximating traditional farmer practice (tillage to $10 \mathrm{~cm}$ with no mulch) had relatively high levels of soil loss. The results indicate a possible role of straw mulch in improving sustainability of cropping on these soils; it reduces the volume of runoff and the concentration of sediment in runoff. The lack of positive tillage effects suggests a limited role for tillage.

\section{CONCLUSION}

Practices that reduce runoff make more water available for crop production and tend to reduce erosion. Cover in contact with the soil surface reduced runoff and sediment concentration even under a millet canopy. We think that the beneficial effects of contact cover arise from several mechanisms. These include protecting the soil surface from raindrop impact, delaying water flow on the soil surface so that the depth of temporary pondage increases and opportunity for infiltration increases, and improving the habitat for macrofauna which create continuous, water conducting macropores. Changes in soil structure due to biological processes are expected to be slow and some years might pass before treatment effects are fully expressed in this experiment. Conclusions drawn from the results during the establishment phase reported here are only tentative. We cannot yet properly evaluate the effect of the perennial species or of zero tillage treatments. Nevertheless, the comparison of traditional and alternative practices shows what can be expected in the initial phase if systems are changed. The results suggest that there may be advantages for soil and water conservation on hardsetting soils in the SAT from mulch-based, rather than tillage-based systems. There appear to be possibilities for developing more productive and more sustainable systems. The challenge will be to develop systems that are economically viable and socially acceptable in the SAT.

\section{ACKNOWLEDGEMENTS}

This experiment was established as part of a collaborative project on soil and water conservation between ICRISAT and the Queensland Department of Primary Industries. The authors wish to acknowledge the encouragement and support of Dr. L.D. Swindale, Director General, ICRISAT and Dr. J.L. Monteith, Director, Resource Management Program, ICRISAT. Drs. J.R. Burford, S.M. Virmani, C.K. Ong, K.L. Sahrawat, R.C. Sachan, N.K. Awadhwal, R.K. Bansal, P. Pathak and J.T. Rego, ICRISAT, contributed to the over- 
all design of the experiment. The authors also acknowledge the valuable role of support staff within the Resource Management Program and Physical Plant Services Section of ICRISAT. Seed of verano and buffel grass was supplied by Y.P. Singh, Director, Forage Research Institute, Mamatdapally. A. Kelly and B. Bauman, QDPI, Toowoomba, assisted with data processing and analysis.

\section{REFERENCES}

Abbott, I., Parker, C.A. and Sills, I.D., 1979. Changes in the abundance of large soil animals and physical properties of soils following cultivation. Aust. J. Soil Res., 17: 343-353.

Akobundu, I.O., 1982. Live mulch crop production in the tropics. World Crops, 34: 125-126, 144-145.

Arndt, W., 1965. The nature of the mechanical impedance to seedlings by soil surface seals. Aust. J. Soil Res., 3: 45-54.

Awadhwal, N.K. and Smith, G.D., 1990. Performance of low-draft tillage implements on a hard setting Alfisol of the SAT in India. Soil Use Manage., 6: 28-31.

Bairathi, R.C., Gupta, N.M. and Seth, S.P., 1974. Effect of different legume crop residues on soil properties, yield, and nutrient uptake by a succeeding wheat crop. J. Indian Soc. Soil Sci., 22: 304-307.

Biswas, T.D., Das, B. and Verma, H.K.G., 1964. Effect of organic matter on some physical properties of soil in the permanent manurial experiment. Bull. Nat. Inst. Sci. India, 26: 142147.

Blackwell, P.S. and Blackwell, J., 1989. The introduction of earthworms to an ameliorated, irrigated duplex soil in south-eastern Australia and the influence on macropores. Aust. J. Soil Res., 27: 807-814.

Bridge, B.J., Mott, J.J., Winter, W.H. and Hartigan, R.J., 1983a. Improvement in soil structure resulting from sown pastures on degraded areas in the dry savanna woodlands of northern Australia. Aust. J. Soil Res., 21: 83-90.

Bridge, B.J., Mott, J.J. and Hartigan, R.J., 1983b. The formation of degraded areas in the dry savanna woodlands of northern Australia. Aust. J. Soil Res., 21: 91-104.

Bristow, K.L., 1988. The role of mulch and its architecture in modifying soil temperature. Aust. J. Soil Res., 26: 269-280.

Bristow, K.L. and Abrecht, D.G., 1989. The physical environment of two semi-arid tropical soils with partial surface mulch cover. Aust. J. Soil Res., 27: 577-587.

Burch, G.J., Mason, I.B., Fischer, R.A. and Moore, I.D., 1986. Tillage effect on soils: physical and hydraulic responses to direct drilling at Lockhart, N.S.W. Aust. J. Soil Res., 24: 377391.

Chan, K.Y. and Mead, J.A., 1988. Surface physical properties of a sandy loam soil under different tillage practices. Aust. J. Soil Res., 26: 549-559.

Charreau, C., 1972. Problemes posés par l'utilisation agricole des sols tropicaux par des cultures annuelles. Agron. Trop., 27: 905-929.

Charreau, C. and Fauck, F., 1970. Mise au point sur l'utilisation agricole des sols de la region de Sefa (Casamance). Agron. Trop., 25: 151-191.

Charreau, C. and Nicou, R., 1971. L'amelioration du profil cultural dans les sols sableux et sablo-argileux de la zone tropicale sèche ouest-africaine et ses incidences agronomiques (d'après les travaux des chercheurs de l'IRAT en Afrique de l'Ouest ). Agron. Trop., 26: 209255, 565-631, 903-978, 1183-1247.

Chopart, J.L., 1989. Effects of tillage on a corn-cotton sequence in Cote d'Ivoire. In: Soil, Crop, 
and Water Management Systems for Rainfed Agriculture in the Sudano-Sahelian Zone. Proceedings of an International Workshop, 7-11 January 1987. International Crops Research Institute for the Semi-Arid Tropics (ICRISAT) Sahelian Center, Niamey, Niger, ICRISAT, Patancheru, India, pp. 325-331.

Clarke, A.L., Greenland, D.J. and Quirk, J.P., 1967. Changes in some physical properties of the surface of an impoverished red brown earth under pasture. Aust. J. Soil Res., 5: 59-68.

Cogle, A.L., Bateman, R.J. and Heiner, D.H., 1991. Conservation cropping systems for the semiarid tropics of northern Queensland, Australia. Aust. J. Exp. Agric., 31: 515-523.

Coughlan, K.J., 1984. The structure of Vertisols. In: J.W. McGarity, E.H. Hoult and H.B. So (Editors), The Properties and Utilization of Cracking Clay Soils. Reviews in Rural Science no. 5, University of New England, Armidale, N.S.W., Australia, pp. 87-96.

Dagg, M. and Macartney, J.C., 1968. The agronomic efficiency of the NIAE mechanized tied ridge system of cultivation. Exp. Agric., 4: 279-294.

Dalal, R.C. and Mayer, R.J., 1986. Long-term trends in fertility of soils under continuous cultivation and cereal cropping in southern Queensland. I. Overall changes in soil properties and trends in winter cereal yields. Aust. J. Soil Res., 24: 265-279.

Ehlers, W., 1975. Observations on earthworm channels and infiltration on tilled and untilled loess soil. Soil Sci., 119: 242-249.

El-Swaify, S.A., Walker, T.S. and Virmani, S.M., 1984. Dryland Management Alternatives and Research Needs for Alfisols in the Semi-Arid Tropics: An Interpretive Summary of the Consultants' Workshop on the State of the Art and Management Alternatives for Optimizing the Productivity of SAT Alfisols and Related Soils, International Crops Research Institute for the Semi-Arid Tropics (ICRISAT) Center, 1-3 December 1983, Patancheru, A.P., India. ICRISAT, Patancheru, A.P.

El-Swaify, S.A., Pathak, P., Rego, T.J. and Singh, S., 1985. Soil management for optimized productivity under rainfed conditions in the semi-arid tropics. Adv. Soil Sci., 1: 1-64.

El-Swaify, S.A., Singh, S. and Pathak, P., 1987. Physical and conservation constraints and management components for SAT Alfisols. In: Alfisols in the Semi-Arid Tropics. Proceedings of the Consultants' Workshop on the State of the Art and Management Alternatives for Optimizing the Productivity of SAT Alfisols and Related Soils, 1-3 December 1983, International Crops Research Institute for the Semi-Arid Tropics (ICRISAT) Center, Patancheru, A.P., India. ICRISAT, Patancheru, A.P., pp. 33-48.

Emerson, W.W., 1983. Inter-particle bonding. In: Soils: An Australian Viewpoint. Academic Press, Melbourne, Australia, pp. 478-498.

Gupta, J.P. and Gupta, G.K., 1986. Effect of tillage and mulching on soil environment and cowpea seedling growth under arid conditions. Soil Tillage Res., 7: 233-240.

Hadimani, A.S. and Perur, N.G., 1971. Measurement of infiltration rate in some of the soils of the Tungabhadra Project Area. J. Indian Soc. Soil Sci., 19: 231-235.

Hadimani, A.S., Hedge, B.R. and Satyanarayana, T., 1982. Management of red soils. In: Review of Soil Research in India. Part 2. Indian Society of Soil Science, New Delhi, India, pp. 689700.

Hamblin A.P., 1984. The effect of tillage on soil surface properties and the water balance of a xeralfic Alfisol. Soil Tillage Res., 4: 543-559.

Hegde, B.R., Channappa, T.C. and Ananda Ram, B.K., 1987. Management alternatives for increased productivity of red soils: experience in Karnataka. In: Alfisols in the Semi-Arid Tropics. Proceedings of the Consultants' Workshop on the State of the Art and Management Alternatives for Optimizing the Productivity of SAT Alfisols and Related Soils, 1-3 December 1983, International Crops Research Institute for the Semi-Arid Tropics (ICRISAT) Center, Patancheru, A.P., India. ICRISAT, Patancheru, A.P., pp. 137-143.

Hoogmoed, W.B., 1987. Some aspects of crust formation on soils in semi-arid regions. In: Alfisols in the Semi-Arid Tropics. Proceedings of the Consultants' Workshop on the State of the 
Art and Management Alternatives for Optimizing the Productivity of SAT Alfisols and Related Soils, 1-3 December 1983, International Crops Research Institute for the Semi-Arid Tropics (ICRISAT) Center, Patancheru, A.P., India. ICRISAT, Patancheru, A.P., pp. 127135.

Hulugalle, N.R. and Lal, R., 1986. Root growth of maize in a compacted gravelly tropical Alfisol as affected by rotation with a woody perennial. Field Crops Res., 13: 33-44.

Jones, M.J., 1973. The organic matter content of the savanna soils of West Africa. J. Soil Sci., 24: 42-53.

Kampen, J., 1980. Farming systems research and technology for the semi-arid tropics. In: Proceedings of the International Symposium on Development and Transfer of Technology for Rainfed Agriculture and the SAT Farmer, 28 August-1 September 1979, International Crops Research Institute for the Semi-Arid Tropics (ICRISAT), Hyderabad, A.P., India. ICRISAT, Patancheru, A.P., pp. 39-56.

Kampen, J. and Burford, J.R., 1980. Production systems, soil-related contraints and potentials in the semi-arid tropics with special reference to India. In: Priorities for Alleviating SoilRelated Constraints to Food Production in the Tropics. Proc. Int. Workshop, 4-8 June 1979, International Rice Research Institute, Los Banos, Laguna, Philippines, pp. 141-165.

Kowal, J., 1970. The hydrology of a small catchment basin at Samaru, Nigeria. III. Assessment of surface runoff under varied land management and vegetation cover. Niger. Agric. J., 7: 120-133.

Kumar Rao, J.V.D.K., Dart, P.J. and Sasstry, P.V.S.S., 1983. Residual effect of pigeonpea ( Cajanus cajan) on yield and nitrogen response of maize. Exp. Agric., 19: 131-141.

Lal, R., 1975. Role of mulching techniques in tropical soil and water management. Technical Bulletin no. 1. International Institute of Tropical Agriculture, Ibadan, Nigeria.

Lal, R., 1977a. Soil management systems and erosion control. In: D.J. Greenland and R. Lal (Editors), Soil Conservation and Management in the Humid Tropics. John Wiley, New York, pp. 93-97.

Lal, R., 1977b. The soil and water conservation problem in Africa: ecological differences and management problems. In: D.J. Greenland and R. Lal (Editors), Soil Conservation and Management in the Humid Tropics. John Wiley, New York, pp. 143-149.

Lal, R., de Vleeschauwer, D. and Nganje, R.M., 1990. Changes in properties of a newly cleared tropical Alfisol as affected by mulching. Soil Sci. Soc. Am. J., 44: 823-827.

Lawes, D.A., 1961. Rainfall conservation and the yield of cotton in northern Nigeria. Emp. J. Exp. Agric., 29: 307-318.

Lawes, D.A., 1963. A new cultivation technique in tropical Africa. Nature, 198: 1328.

Lawes, D.A., 1966. Rainfall conservation and yields of sorghum and groundnuts in northern Nigeria. Exp. Agric., 2: 139-146.

Loch, R.J., Thomas, E.C. and Donnollan, T.E., 1987. Interflow in a tilled, crackling clay soil under simulated rain. Soil Tillage Res., 9: 45-63.

McCown, R.L., 1987. An agroecological approach to management of SAT Alfisols. In: Alfisols in the Semi-Arid Tropics. Proceedings of the Consultants' Workshop on the State of the Art and Management Alternatives for Optimizing the Productivity of SAT Alfisols and Related Soils, 1-3 December 1983, International Crops Research Institute for the Semi-Arid Tropics (ICRISAT) Center, Patancheru, A.P., India. ICRISAT, Patancheru, A.P., pp. 175-185.

Mullins, C.E., Young, I.M., Bengough, A.G. and Ley, G.J., 1987. Hardsetting soils. Soil Use Manage., 3: 79-83.

Mullins, C.E., MacLeod, D.A., Northcote, K.H., Tisdall, J.M. and Young, I.M., 1990. Hardsetting soils: behaviour, occurrence, and management. Adv. Soil Sci., 11: 37-108.

Murthy, R.S., Hirekerur, L.R., Deshpande, S.B. and Rao, B.V.V., 1982. Benchmark Soils of India. Morphology, characteristics and classsification for resource management. National Bureau of Soil Survey and Land Use Planning, Nagpur, India. 